Marquette University

e-Publications@Marquette

Physics Faculty Research and Publications

Physics, Department of

8-1-2007

\title{
Modified Active Site Coordination in a Clinical Mutant of Sulfite Oxidase
}

Christian J. Doonan

University of Saskatchewan

Heather L. Wilson

Duke University

K.V.Rajagopalan

Duke University

Robert M. Garrett

Duke University

Brian Bennett

Marquette University, brian.bennett@marquette.edu

See next page for additional authors

Accepted version. Journal of the American Chemical Society, Vol. 129, No. 30 (August 2007):

9421-9428. DOI. (C) 2007 American Chemical Society. Used with permission.

Brian Bennett was affiliated with Medical College of Wisconsin at the time of publication. 


\section{Authors}

Christian J. Doonan, Heather L. Wilson, K. V. Rajagopalan, Robert M. Garrett, Brian Bennett, Roger C. Prince, and Graham N. George 


\title{
Modified Active Site Coordination in a Clinical Mutant of Sulfite Oxidase
}

\author{
Christian J. Doonan \\ Department of Geological Sciences, \\ University of Saskatchewan, Saskatoon, \\ Saskatchewan, Canada \\ Heather L. Wilson \\ Department of Biochemistry, School of Medicine, \\ Duke University, \\ Durham, NC \\ K.V. Rajagopalan \\ Department of Biochemistry, School of Medicine, \\ Duke University, \\ Durham, NC \\ Robert M. Garrett \\ Department of Biochemistry, School of Medicine, \\ Duke University, \\ Durham, NC \\ Brian Bennett \\ Department of Biophysics, Medical College of Wisconsin, \\ Milwaukee, WI \\ Roger C. Prince \\ ExxonMobil Biomedical Sciences, Inc., \\ Annandale, NJ
}

Journal of the American Chemical Society, Vol 129, No. 30 (August 1, 2007): pg. 9421-9428. DOI. This article is ( American Chemical Society and permission has been granted for this version to appear in e-Publications@Marquette. American Chemical Society does not grant permission for this article to be further copied/distributed or hosted elsewhere without the express permission from American Chemical Society. 
NOT THE PUBLISHED VERSION; this is the author's final, peer-reviewed manuscript. The published version may be accessed by following the link in the citation at the bottom of the page.

\section{Graham N. George \\ Department of Geological Sciences, University of Saskatchewan, Saskatoon, Saskatchewan, Canada}

\section{Abstract}

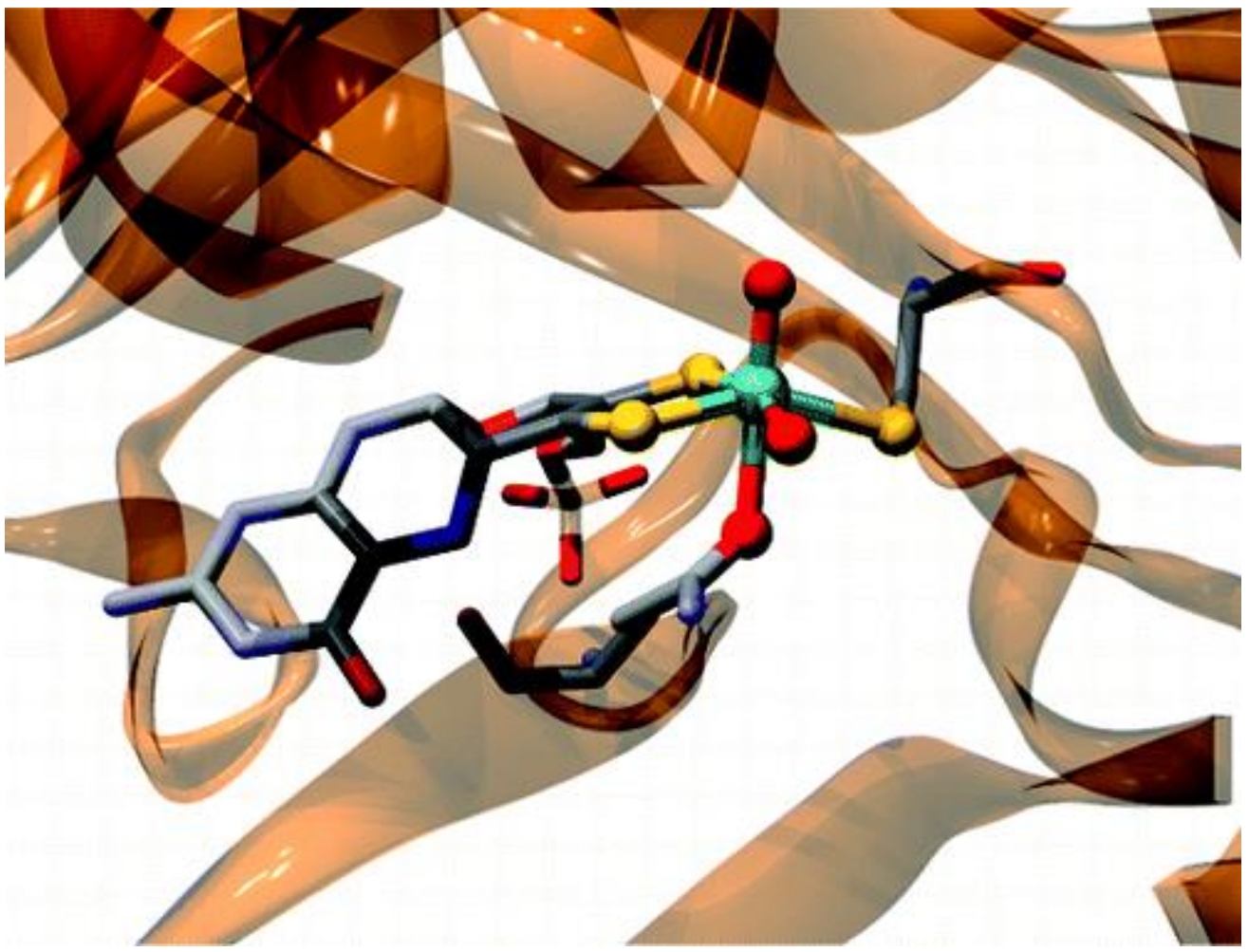

The molybdenum site of the Arginine $160 \rightarrow$ Glutamine clinical mutant of the physiologically vital enzyme sulfite oxidase has been investigated by a combination of X-ray absorption spectroscopy and density functional theory calculations. We conclude that the mutant enzyme has a six-coordinate pseudo-octahedral active site with coordination of Glutamine $\mathrm{O}_{\varepsilon}$ to molybdenum. This contrasts with the wild-type enzyme which is fivecoordinate with approximately square-based pyramidal geometry. This difference in the structure of the molybdenum site explains many of the properties of the mutant enzyme which have previously been reported. 
NOT THE PUBLISHED VERSION; this is the author's final, peer-reviewed manuscript. The published version may be accessed by following the link in the citation at the bottom of the page.

\section{Introduction}

Sulfite oxidase (SO) is an oxo-transferase enzyme responsible for the physiologically vital oxidation of sulfite to sulfate. ${ }^{1}$ Residing in the mitochondrial inner-membrane space, the enzyme is dimeric with a subunit mass of about 52000 . Each monomer contains molybdenum associated with a single pterin cofactor (Moco) and a cytochrome $b_{5}$ type heme. The two-electron oxidation of sulfite to sulfate is known to occur at the molybdenum site, which is reduced from $\mathrm{Mo}^{\mathrm{VI}}$ to $\mathrm{Mo}^{\mathrm{IV}}$ in the process. The catalytic cycle is completed with reoxidation of the molybdenum first to $\mathrm{Mo}^{\mathrm{v}}$, and then to $\mathrm{Mo}^{\mathrm{VI}}$, by intramolecular electron transfer to the cytochrome $b_{5}$ site, with cytochrome $c$ serving as the external electron acceptor. ${ }^{2,3}$

$$
\begin{aligned}
& \text { Enzyme-Mo }{ }^{\mathrm{VI}}+\mathrm{SO}_{3}^{2-}+\mathrm{H}_{2} \mathrm{O} \rightarrow \\
& \quad \text { Enzyme- } \mathrm{Mo}^{\mathrm{IV}}+\mathrm{SO}_{4}{ }^{2-}+2 \mathrm{H}^{+}
\end{aligned}
$$

With the exception of nitrogenase, ${ }^{4}$ all molybdenum enzymes that have been described to date contain a novel pyranopterin-dithiolene cofactor (known as molybdopterin) in which the Mo atom is coordinated by the dithiolene moiety (Figure 1a)..$^{5,6}$ In sulfite oxidase, the molybdenum atom is coordinated by two sulfur donors from one dithiolene, two terminal oxygen atoms, and one additional sulfur donor from a cysteine (Cys ${ }^{185}$ in chicken SO or Cys ${ }^{207}$ in human $\mathrm{SO}) .{ }^{7}$ As one of the most intensively studied molybdoenzymes, SO can be regarded as the prototypical member of a family of proteins possessing di-oxo molybdenum sites in the fully oxidized Mo ${ }^{\mathrm{VI}}$ form. ${ }^{10}$

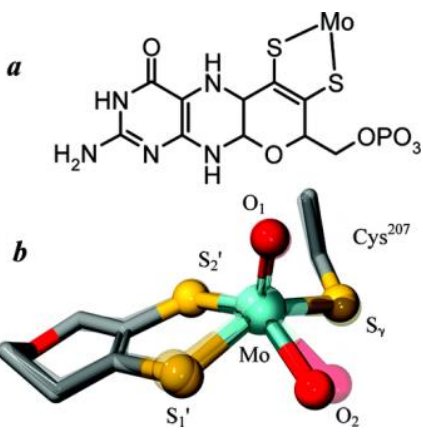

Figure 1 (a) Schematic structure for the molybdopterin molybdenum cofactor. (b) Crystal structure of the active site of photoreduced (probably Mo ${ }^{\mathrm{IV}}$ ) wild-type and R138Q chicken sulfite oxidases. Only the pyrano-dithiolene parts of the molybdopterin

Journal of the American Chemical Society, Vol 129, No. 30 (August 1, 2007): pg. 9421-9428. DOI. This article is @ American Chemical Society and permission has been granted for this version to appear in e-Publications@Marquette. American Chemical Society does not grant permission for this article to be further copied/distributed or hosted elsewhere without the express permission from American Chemical Society. 
moiety are shown for clarity. The structure determined for wild-type SO is shown as opaque, while the R138Q structure is shown as a partly transparent model.

A number of mutations of human SO are known that have very serious pathological consequences, including one recently implicated in a Nevada Leukemia cluster. ${ }^{11,12} \operatorname{Arg}^{160} \rightarrow \mathrm{Gln}$ (R160Q) is a lethal mutation that has been identified in a number of children. ${ }^{8,9}$ In this mutant the positively charged arginine residue that is located close to the Moco site is replaced by a neutral glutamine. This mutant SO and the equivalent chicken R138Q mutant have been extensively studied by a number of techniques including enzyme kinetics, ${ }^{7}$ protein crystallography, ${ }^{13}$ and laser flash photolysis. ${ }^{14}$ The mutant has altered steady-state kinetic parameters ${ }^{7}$ and shows remarkably decreased rates of intramolecular electron transfer. ${ }^{14}$ The greatly increased $K_{\mathrm{m}}$ for sulfite displayed by the mutant has led to the proposal that Arg ${ }^{160}$ functions to attract sulfite to the active site.

All crystal structures of SO that have been reported to date have photoreduced Mo sites (probably $\mathrm{Mo}^{\mathrm{IV}}$ ) due to the large X-ray dose required for crystallographic data acquisition. ${ }^{15}$ Protein crystallography of wild-type chicken SO shows a five-coordinate molybdenum site, with an arginine-rich substrate binding pocket $\sim 5 \AA$ from molybdenum. Arg ${ }^{138}$ forms a part of this binding pocket and is the closest of these amino acids to Mo, in conformity with its proposed role. Protein crystallography of $\mathrm{R} 138 \mathrm{Q}$ chicken $\mathrm{SO}$ reveals modification of the $5 \AA$ pocket with both R138 and R450 affected, with the latter being displaced from its wild-type position. The structure of the molybdenum site, which once again is photoreduced, is fivecoordinate ${ }^{13}$ and very similar to that of wild-type enzyme. ${ }^{7}$ Figure $1 \mathrm{~b}$ compares the protein crystal structures for the molybdenum site of $\mathrm{R} 138 \mathrm{Q}$ and wild-type chicken $\mathrm{SO}^{7,14}$ with the atoms superimposed to illustrate the local similarity; all atoms can be superimposed to better than $0.5 \AA$, which is close to the positional error expected for small atoms close to a large atom (i.e., molybdenum) at the resolution of the crystal structures. ${ }^{7,14}$ Thus, despite modified properties, a clear role for the Mo site in the molecular basis for the incompetence of this clinical mutant remains unclear. We present herein a high-resolution $\mathrm{X}$-ray absorption spectroscopic study of the oxidized and reduced Mo $\mathrm{MI}^{\mathrm{I}}$ R160Q active site of human SO and show active site structural 
differences between wild-type and mutant in both oxidized and reduced forms.

\section{Materials and Methods}

Sample Preparation. R160Q sulfite oxidase was prepared as described by Garrett et al. ${ }^{8}$ All reagents were obtained from SigmaAldrich and were of the highest quality available. Samples were prepared in 25 mM MOPS buffer $\mathrm{pH} 7.0$, unless otherwise stated. Reduced enzyme for XAS measurements (approximately $1 \mathrm{mM} \mathrm{Mo}$ ) was generated by treatment with $10 \mathrm{mM}$ sodium dithionite solution containing a trace $(\sim 4 \mu \mathrm{M})$ of methyl viologen for approximately $30 \mathrm{~s}$. Samples for XAS were transferred to $\left(2 \times 10 \times 10 \mathrm{~mm}^{3}\right)$ lucite sample cuvettes, rapidly frozen in cold isopentane at $-140{ }^{\circ} \mathrm{C}$, and then transferred to liquid nitrogen prior to $\mathrm{X}$-ray absorption spectroscopic data collection. Samples for EPR spectroscopy were approximately 0.1 $\mathrm{mM}$ Mo in a mixed buffer system of $0.1 \mathrm{M}$ MES + 0.1 M Bis Tris Propane from which chloride was excluded, and the $\mathrm{Mo}^{\vee}$ oxidation state was generated either by redox titration or by addition of $1 \mathrm{mM}$ (an excess) sulfite.

XAS Data Collection. XAS measurements were conducted at the Stanford Synchrotron Radiation Laboratory (SSRL) with the SPEAR storage ring containing between 80 and $100 \mathrm{~mA}$ at $3.0 \mathrm{GeV}$. Molybdenum K-edge data were collected on the structural molecular biology XAS beamline 9-3 operating with a wiggler field of $2 \mathrm{~T}$. A $\mathrm{Si}(220)$ double-crystal monochromator was used. Beamline 9-3 is equipped with a rhodium-coated vertical collimating mirror upstream of the monochromator and a downstream bent-cylindrical focusing mirror (also rhodium-coated). Harmonic rejection was accomplished by setting the cutoff angle of the mirrors to $23 \mathrm{keV}$. Incident and transmitted X-ray intensities were monitored using argon- or nitrogenfilled ionization chambers. X-ray absorption was measured as the Mo Ka fluorescence excitation spectrum using a 30 element germanium array detector. ${ }^{16}$ During data collection, samples were maintained at a temperature of approximately $10 \mathrm{~K}$ using an Oxford instruments liquid helium flow cryostat. For each sample, five scans were accumulated, and the energy was calibrated by reference to the absorption of a molybdenum foil measured simultaneously with each scan, assuming a 
lowest energy inflection point of $20003.9 \mathrm{eV}$. The energy threshold of the extended X-ray absorption fine structure (EXAFS) oscillations was assumed to be $20025.0 \mathrm{eV}$.

XAS Data Analysis. The EXAFS oscillations $X(k)$ were quantitatively analyzed by curve-fitting using the EXAFSPAK suite of computer programs ${ }^{17}$ as previously described ${ }^{18,19}$ using $a b$ initio theoretical phase and amplitude functions calculated using the program FEFF version $8.25 .{ }^{20,21}$ No smoothing, filtering, or related operations were performed on the data.

EPR Spectroscopy. Electron paramagnetic resonance (EPR) spectroscopy and data reduction were performed as described by George et al. ${ }^{22}$ Spectra were collected using a Varian E109, JEOL RE1X, or Bruker Elexsys instrument. Redox titrations followed the method of Dutton ${ }^{23}$ using $40 \mu \mathrm{M} \mathrm{N}$-methylphenazonium methosulfate, $N$-ethylphenazonium ethosulfate, 2-hydroxy-1,4-naphthoquinone, 2hydroxy-1,4-anthraquinone, indigo disulfonate, indigo trisulfonate, and benzyl viologen as redox mediators between the protein and the platinum measuring electrode. Potentials were measured with respect to a saturated calomel electrode but are reported with respect to the hydrogen electrode by assuming that the calomel electrode has a potential of $+247 \mathrm{mV}$. ${ }^{24}$ We used $50 \mathrm{mM}$ bis-tris propane buffers, except for samples at $\mathrm{pH} 6$ for which 50 mM MES was used. Anions such as chloride and sulfate were excluded from the buffers $(\mathrm{NaOH}$ or acetic acid were used to adjust $\mathrm{pH}$ ).

Molecular Modeling. Density Functional Theory (DFT) molecular modeling used the program Dmol3 Materials Studio Version 3.2. ${ }^{25,26}$ We expect bond-length accuracies of around $0.05 \AA$ and good estimates of energetic trends between postulated molecular entities. The Becke exchange ${ }^{27}$ and Perdew correlation ${ }^{28}$ functionals were used to calculate both the potential during the self-consistent field procedure and the energy. Double numerical basis sets included polarization functions for all atoms. Calculations were spinunrestricted, and all electron relativistic core potentials were used. No symmetry constraints were applied, and optimized geometries used energy tolerances of $2.0 \times 10^{-5}$ hartree. 
NOT THE PUBLISHED VERSION; this is the author's final, peer-reviewed manuscript. The published version may be accessed by following the link in the citation at the bottom of the page.

\section{Results and Discussion}

Mo K Near-Edge X-ray Absorption Spectra. Figure 2A compares the molybdenum $\mathrm{K}$ near-edge spectrum of oxidized and reduced R160Q SO with corresponding spectra for samples of wildtype enzyme. Near-edge spectra are comprised of transitions of the core-electron (i.e., Mo 1s) to bound states involving the frontier molecular orbitals of the system and are thus sensitive to electronic structure and hence to geometry. The lowest energy peak at ca. $20009 \mathrm{eV}$ is observed in both spectra and is attributed to a Mo $1 \mathrm{~s} \rightarrow$ $\mathrm{Mo}=\mathrm{O} \Pi^{*}$ transition. ${ }^{29}$ The contrasting spectra of wild-type and R160Q SO shown in Figure 2 clearly indicate structural differences between wild-type and mutant active sites.
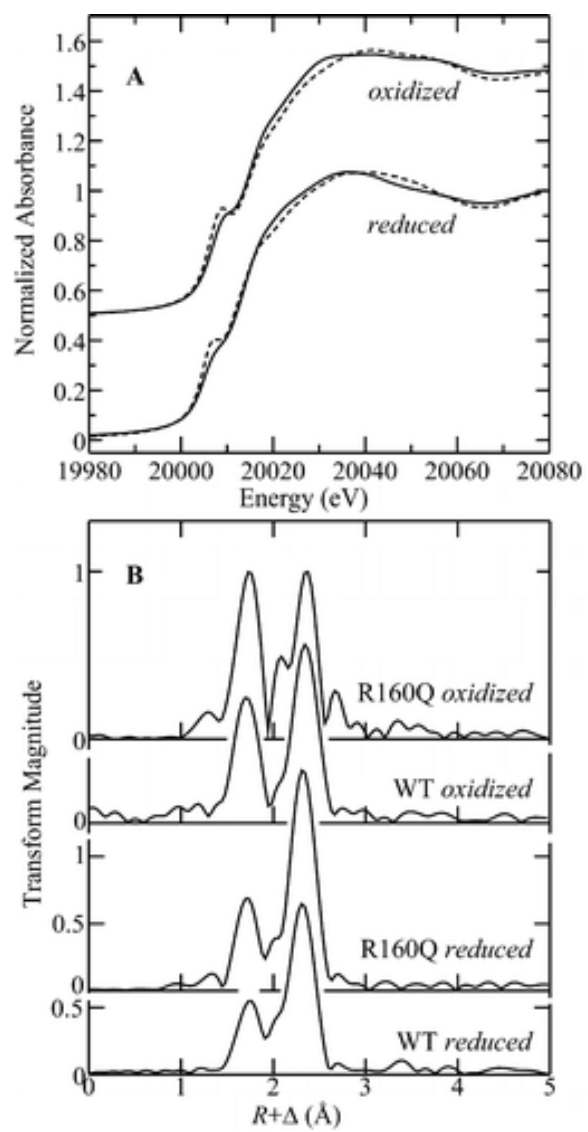

Figure 2 (A) Comparison of the molybdenum K near-edge spectra R160Q human sulfite oxidase (solid lines) with those of wild-type enzyme (broken lines), in oxidized $(a)$ and reduced $(b)$ forms. (B) Comparison of Mo K-edge EXAFS Fourier transforms of wild-type and R160Q human sulfite oxidase in both oxidized and reduced forms. Transforms are phase corrected for Mo-S backscattering and are restricted to the same $k$-range $\left(1-18 \AA^{-1}\right)$. 
NOT THE PUBLISHED VERSION; this is the author's final, peer-reviewed manuscript. The published version may be accessed by following the link in the citation at the bottom of the page.

Molybdenum K-Edge EXAFS. Figure 2B compares the EXAFS Fourier transforms of wild-type and R160Q SO. The differences between the mutant and wild-type transforms clearly show that the mutant has modified Mo coordination in both oxidized and reduced forms. Figure 3 shows the extended X-ray absorption fine structure (EXAFS) Fourier transform of R160Q SO in oxidized and reduced forms, together with the results of the curve-fitting analysis. As we have discussed above, the only available quantitative structural information on oxidized sulfite oxidase is from EXAFS spectroscopy. For oxidized wild-type SO only two different EXAFS contributions are resolved, even with data extending to $25 \AA^{-1} .^{30}$ The data are described by two $\mathrm{Mo}=\mathrm{O}$ at an average distance of $1.72 \AA$ and three Mo $-\mathrm{S}$ at $2.42 \AA$, with individual $\mathrm{MO}=\mathrm{O}$ and $\mathrm{Mo}-\mathrm{S}$ bond lengths differing by less than $0.05 \AA .{ }^{30}$ In contrast, the EXAFS of oxidized R160Q enzyme requires a total of four different EXAFS interactions to fit the data, and this is illustrated in Figure 4. Curve-fitting analysis shows two $\mathrm{Mo}=\mathrm{O}$ at $1.73 \AA$, one $\mathrm{Mo}-\mathrm{O}$ at $2.22 \AA$, two Mo $-\mathrm{S}$ at $2.44 \AA$, and a long Mo $-\mathrm{S}$ at $2.58 \AA$ (Table 1 ), which indicates a total of six ligands to Mo. ${ }^{31}$ For molybdenum, a likely geometry for such a six-coordinate species is pseudo-octahedral, and in this case two ligands will be positioned trans to each of the two oxo ligands and significant trans-effect elongation of these bonds is expected. The long Mo $-\mathrm{S}$ bond detected by EXAFS is thus likely to originate from sulfur coordination trans to one of the two $\mathrm{Mo}=\mathrm{O}$ groups. Examination of the Cambridge Structural database ${ }^{33}$ searching for dioxo $\mathrm{Mo}^{\mathrm{VI}}$ species with a Mo $-\mathrm{S}$ positioned trans to a Mo $=\mathrm{O}$ indicates a trans-effect $\mathrm{Mo}-\mathrm{S}$ bond-length range of 2.53 to 2.78 $\AA$. By comparison the mean $\mathrm{Mo}-\mathrm{S}$ bond length for dioxo $\mathrm{Mo}^{\mathrm{VI}}$ species with sulfur coordinated cis to both $\mathrm{Mo}=\mathrm{O}$ groups is $2.42 \AA .{ }^{33}$ The observed bond length for trans ligands depends approximately on the $\mathrm{O}=\mathrm{Mo}-\mathrm{S}$ bond angle, with the most nearly linear $\left(\sim 166^{\circ}\right)$ having the longest, and the most acute $\left(\sim 144^{\circ}\right)$ having the shortest Mo $-\mathrm{S}$ bond length. The $2.58 \AA \mathrm{Mo}-\mathrm{S}$ bond length determined by EXAFS is thus within the range of $\mathrm{Mo}=\mathrm{O}$ trans-effect elongated sulfur ligands and is notably absent in wild-type SO. ${ }^{30}$ The correlation observed in the data from the Cambridge Structural database ${ }^{34}$ suggests an $\mathrm{O}=\mathrm{Mo}-\mathrm{S}$ bond angle in the range $145^{\circ}$ to $154^{\circ}$. The EXAFS also shows two Mo $-\mathrm{S}$ bonds at bond lengths of $2.44 \AA$, with no $\mathrm{Mo}=\mathrm{O}$ trans-elongation. Thus, our EXAFS data suggest a six-coordinate site arising from coordination of an additional Mo - $\mathrm{O}$ ligand. These findings are 
NOT THE PUBLISHED VERSION; this is the author's final, peer-reviewed manuscript. The published version may be accessed by following the link in the citation at the bottom of the page.

consistent with the marked difference observed in the UV-visible absorption spectra between the isolated Mo domains ${ }^{35}$ of wild type SO and the R160Q mutant, ${ }^{8}$ as an altered active site structure is expected to give rise to a quite distinct electronic spectrum.

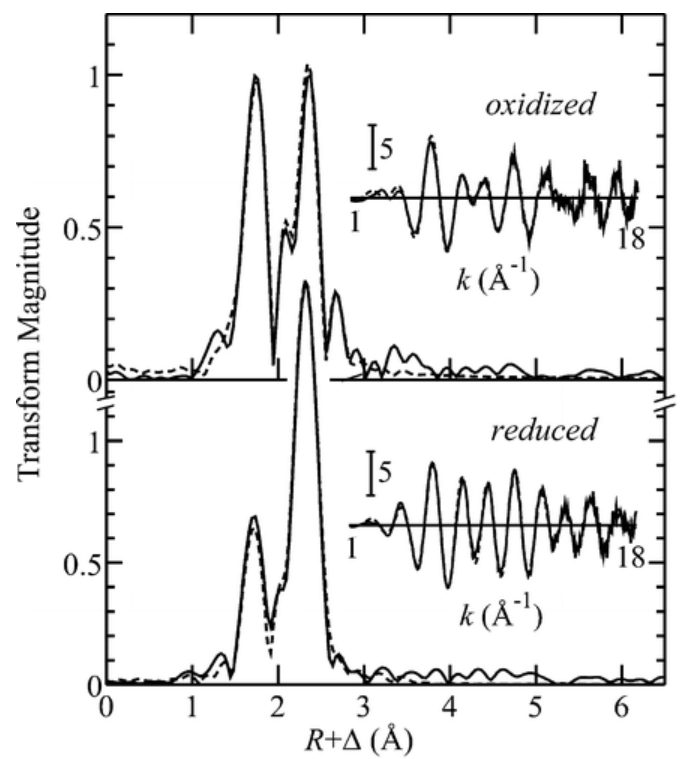

Figure 3 Mo K-edge EXAFS Fourier Transforms (Mo-S phase-corrected), plus the EXAFS spectra (shown in insets), for oxidized and reduced R160Q sulfite oxidase. Solid lines show the experimental data, and broken lines show the best fits using the parameters given in Table 1.

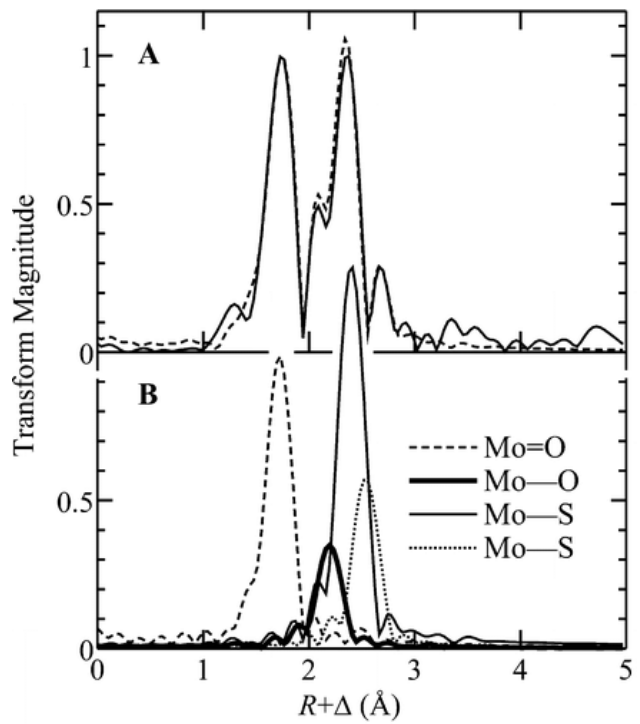

Figure 4 (A) Mo K-edge EXAFS Fourier transform (Mo - $S$ phase-corrected) of oxidized $\mathrm{R} 160 \mathrm{Q}$ sulfite oxidase. The solid line shows experimental data, and the broken line the best fit. (B) Breakdown of the fit, with the Fourier transform of the four individual EXAFS contributions shown in different line styles.

Journal of the American Chemical Society, Vol 129, No. 30 (August 1, 2007): pg. 9421-9428. DOI. This article is (C) American Chemical Society and permission has been granted for this version to appear in e-Publications@Marquette. American Chemical Society does not grant permission for this article to be further copied/distributed or hosted elsewhere without the express permission from American Chemical Society. 
NOT THE PUBLISHED VERSION; this is the author's final, peer-reviewed manuscript. The published version may be accessed by following the link in the citation at the bottom of the page.

Table 1. EXAFS Curve-Fitting Parameters ${ }^{a}$

Mo-S Mo-O

\begin{tabular}{|c|c|c|c|c|c|c|}
\hline sample & $N R$ & $\sigma^{2}$ & $N R$ & $\sigma^{2}$ & $\Delta E_{0}$ & $F$ \\
\hline \multirow[t]{2}{*}{ R160Q, oxidized } & $22.442(3)$ & $0.0021(1)$ & $21.725(2)$ & $0.0023(1)$ & $-10.7(6)$ & 0.261 \\
\hline & $12.580(4)$ & $0.0023(2)^{b}$ & $12.217(5)$ & $0.0025(9)$ & & \\
\hline \multirow[t]{5}{*}{ R160Q, reduced $\mathrm{pH} 7$} & $32.413(1)$ & $0.0027(1)$ & $11.706(1)$ & $0.0015(1)$ & $-10.3(3)$ & 0.168 \\
\hline & & & $12.221(4)$ & $0.0020(2)$ & & \\
\hline & $32.409(2)$ & $0.0029(1)$ & $11.707(1)$ & $0.0015(1)$ & $-9.1(5)$ & 0.165 \\
\hline & & & $12.215(6)$ & $0.0028(8)$ & & \\
\hline & & & $12.32(1)$ & $0.0031(8)$ & & \\
\hline
\end{tabular}

${ }^{a}$ Coordination numbers, $N$, interatomic distances, $R(\AA)$, Debye-Waller factors, $\sigma^{2}$ $\left(\AA^{2}\right)$, and threshold energy shifts, $\Delta E_{0}(\mathrm{eV})$. Values in parentheses are the estimated standard deviations (precisions) obtained from the diagonal elements of the covariance matrix. The accuracies will be much greater than these values and are generally accepted to be $\pm 0.02 \AA$ for bond lengths and $\pm 20 \%$ for coordination numbers and Debye-Waller factors. The fit-error function $F$ is defined as $F=$ $\sqrt{\sum k^{6}\left(\chi_{\text {caled }}-\chi_{\text {expt }}\right)^{2} / \sum \chi_{\text {expt }}^{2}}$, where the summations are over all data points included in the refinement. ${ }^{b}$ The value for this Debye-Waller factor is smaller than might be expected for such a long Mo - S interaction; however we note that similar Debye-Waller factors (i.e., $0.0026 \AA^{2}$ ) have been observed for compounds showing pronounced $\mathrm{Mo}=\mathrm{O}$ induced trans-elongation of Mo $-\mathrm{S}$ bond lengths. ${ }^{32}$

The EXAFS analysis of the data from reduced R160Q SO indicates a single $\mathrm{Mo}=\mathrm{O}$ at $1.71 \AA$, plus three equivalent (within the resolution of our measurements $\sim 0.086 \AA$ ) $M o-S$ at $2.41 \AA$, and either one or two Mo-O. A single Mo-O gives a bond length of 2.22 $\AA$, while two different Mo-O give bond lengths of 2.21 and $2.32 \AA$ and a slightly better fit (Table 1 ). Unfortunately, this improvement is marginal, and we cannot unambiguously determine whether one or two Mo - O ligands are present. ${ }^{36}$ The results from protein crystallography clearly indicate a five-coordinate site, which favors the first alternative, but the EPR spectroscopy (considered below) indicates the presence of multiple forms of the active site in the reduced enzyme.

Electron Paramagnetic Resonance Spectroscopy. Wild-type SO gives MoV EPR signals that can be divided into three different categories (Table 2). The high-pH signal occurs at low anion concentrations and at high-pH values, while the low- $\mathrm{pH} / \mathrm{Cl}^{-}$signal occurs at low $\mathrm{pH}$ and high chloride. ${ }^{37,38} \mathrm{~A}$ third category of signals are those from oxy-anion complexes, which tend to form at low $\mathrm{pH}$ and high oxy-anion concentrations. SO MoV EPR signals arising from anion

Journal of the American Chemical Society, Vol 129, No. 30 (August 1, 2007): pg. 9421-9428. DOI. This article is (C) American Chemical Society and permission has been granted for this version to appear in e-Publications@Marquette. American Chemical Society does not grant permission for this article to be further copied/distributed or hosted elsewhere without the express permission from American Chemical Society. 
complexes have been described for phosphate, arsenate, and sulfite (or sulfate). ${ }^{22,37,39-42}$ Analysis of the ${ }^{31} \mathrm{P}$ hyperfine interaction of the phosphate signal and structural analysis of the arsenate signal using EXAFS indicate that in both cases the anion is coordinated to molybdenum via one of its oxygen ligands. ${ }^{22,39,40}$

Table 2. Mo EPR Spin Hamiltonian Parameters ${ }^{a}$

$\begin{array}{lllll}\text { sample } & \text { parameter } & x & y & z \\ \text { R160Q high pH } & \mathbf{g} & 1.9526 & 1.9636 & 1.9875 \\ & \Delta & 0.38 & 0.39 & 0.30 \\ \text { R160Q low pH 1 } & \mathbf{A}\left({ }^{1} \mathrm{H}\right)^{b} & -10 & -10 & 20 \\ & \mathbf{g} & 1.9514 & 1.9708 & 2.0061 \\ \text { R160Q low pH 2 } & \Delta & 0.22 & 0.27 & 0.32 \\ & \mathbf{g} & 1.9391 & 1.9604 & 1.9978 \\ & \Delta & 0.27 & 0.24 & 0.30\end{array}$

${ }^{a} g$-Values, line widths $(\mathrm{mT})$, and hyperfine $(\mathrm{MHz})$ obtained from the computer simulations shown in Figure $5 .{ }^{b}$ Note that these are approximate values obtained by computer simulation using non-colinear $\mathbf{g}$ and $\mathbf{A}$ at the trimagic angle. ${ }^{49}$

Figure 5 shows the three primary Mo(V) EPR signals that can be obtained from $\mathrm{R} 160 \mathrm{Q}$ SO. The signals are related by $\mathrm{pH}$, with at least two different $\mathrm{p} K_{\mathrm{a}}$ values involved. Figure $5 \mathrm{~A}$ shows a $\mathrm{pH}$ titration of $\mathrm{R} 160 \mathrm{Q}$ Mo(V) EPR signals. The high-pH signal (Figure 5Aa) is very similar to that observed for wild-type SO, suggesting a nearly identical coordination at high $\mathrm{pH}$, and is in agreement with the reduced sites determined by crystallography. The two low-pH signals are related to each other, and the high-pH signal is by ionizable groups (amino acid side chains) with $\mathrm{p} K_{\mathrm{a}}$ values of 8.0 and 6.1 , respectively:

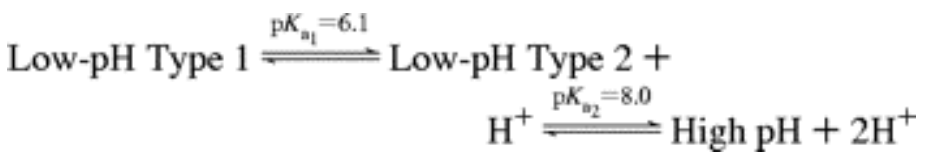

The two low-pH signals show no clear structure from proton hyperfine interactions and are essentially identical when developed in deuterated water (not illustrated). Figure 6 compares the MoV EPR redox titrations of wild-type and $\mathrm{R} 160 \mathrm{Q}$ SO. The conditions for wildtype enzyme were chosen so as to produce a single Mo ${ }^{\vee}$ EPR signal under the two conditions used (the low $\mathrm{pH} / \mathrm{Cl}^{-}$species at low $\mathrm{pH}$ and the high $\mathrm{pH}$ species at high $\mathrm{pH}$ ), and the conditions for the R160Q low$\mathrm{pH}$ redox titration were chosen so that both the low-pH type 1 and

Journal of the American Chemical Society, Vol 129, No. 30 (August 1, 2007): pg. 9421-9428. DOI. This article is (C) American Chemical Society and permission has been granted for this version to appear in e-Publications@Marquette. American Chemical Society does not grant permission for this article to be further copied/distributed or hosted elsewhere without the express permission from American Chemical Society. 
type 2 signals would be observed. No difference in redox behavior was detected between the type 1 and type 2 low pH signals. At $\mathrm{pH} 9$ the midpoint potentials $E_{m}$ of wild-type enzyme are $-206 \mathrm{mV}\left(\mathrm{Mo}^{\mathrm{IV}} / \mathrm{Mo}^{\mathrm{V}}\right.$ ) and $+30 \mathrm{mV}\left(\mathrm{MoV}^{\mathrm{V}} \mathrm{Mo}^{\mathrm{VI}}\right)$, and these are shifted to lower values in R160Q SO, -247 and $-27 \mathrm{mV}$ for $E_{m}\left(\mathrm{Mo}^{\mathrm{IV}} / \mathrm{Mo}^{\mathrm{v}}\right)$ and $E_{m}\left(\mathrm{Mov}^{\mathrm{V}} / \mathrm{Mo}^{\mathrm{VI}}\right)$, respectively. The $E_{m}$ values are shifted to higher values at lower $\mathrm{pH}$ (wild-type $\mathrm{pH} 6.0,0.1 \mathrm{M} \mathrm{Cl}, \mathrm{R} 160 \mathrm{Q} \mathrm{pH} 6.5): E_{m}\left(\mathrm{Mo}^{\mathrm{IV}} / \mathrm{Mo}^{\mathrm{V}}\right)=-62 \mathrm{mV}$ and $E_{m}\left(\mathrm{MoV}^{\mathrm{V}} \mathrm{Mo}^{\mathrm{VI}}\right)=+150 \mathrm{mV}$, for wild-type; $-127 \mathrm{mV}$ and $+122 \mathrm{mV}$ for R160Q SO, respectively. This is close to the theoretically expected $-59 \mathrm{mV}$ per $\mathrm{pH}$ unit change if the reactions involve a single proton per electron, although we note that the different molybdenum coordination environments of the different signal-giving species will complicate the relationship. Compared to wild-type SO, R160Q is thus effectively harder to reduce, and the reduced mutant enzyme will itself be a better reducing agent.
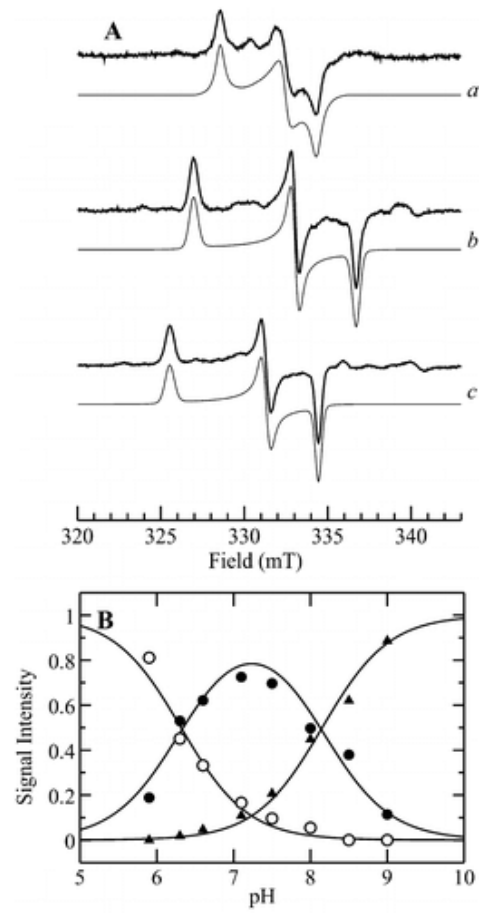

Figure $5 \mathrm{Mo}^{\vee}$ EPR spectra of R160Q sulfite oxidase. (A) The three different types of EPR spectra detected for R160Q SO aligned to a microwave frequency of $9.1367 \mathrm{GHz}$. Experimental spectra are shown as bold lines, while simulations computed using the parameters given in Table 2 are shown as fine lines. $a$ shows the high-pH spectrum, $b$ shows the low-pH type 2, and $c$ shows the low-pH type 1 spectrum. (B) pH

dependence of the $\mathrm{Mo}^{\vee}$ EPR signals. The points show the experimental $\mathrm{Mo}^{\vee}$ integrated EPR signal intensity: - low-pH type 1, $\triangle$ low-pH type 2, and $\circ$ high $\mathrm{pH}$. The lines are computed curves for the equilibrium discussed in the text, using $\mathrm{p} K_{\mathrm{a}}$ values of 6.1 and 8.0 . 


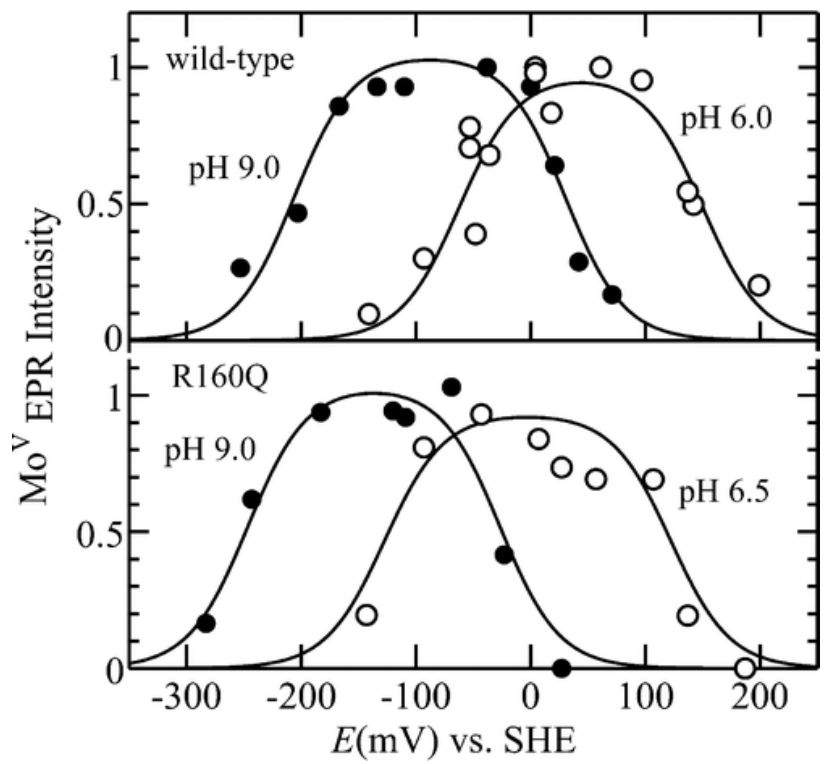

Figure $6 \mathrm{Mo}^{\vee}$ redox titrations of wild-type and R160Q sulfite oxidase, under conditions for high-pH $\cdot$ and low-pH $\circ \mathrm{Mo}^{\vee}$ EPR signals. For wild-type enzyme the low-pH enzyme had $0.1 \mathrm{M} \mathrm{NaCl}$ added in order to ensure $100 \%$ of the low-pH species.

The transition between wild-type $\mathrm{SO}$ low-pH and high-pH signals depends on an ionizable group with a $\mathrm{p} K_{\mathrm{a}}$ of less than 6.8 in the absence of high concentrations of exogenous anions. It seems probable that the ionizable group detected by Mov EPR in wild-type SO is one of the two ionizable groups that influence the EPR spectra of R160Q SO. These are likely to be amino acid side chains in proximity to the Moco site. One candidate is $\mathrm{Tyr}^{343}$ which has been implicated as being important in catalytic turnover of the enzyme ${ }^{43}$ and in electron transfer between the cytochrome $b_{5}$ moiety and the Moco. ${ }^{44}$ Furthermore, the bacterial sulfite dehydrogense of Starkeya novella ${ }^{45,46}$ (previously Thiobacillus novella) only shows high-pH Mov EPR signals; ${ }^{45,47}$ however when $\mathrm{Tyr}^{236}$ (the analogous amino acid to SO $\mathrm{Tyr}^{343}$ ) is modified to a phenylalanine, characteristic low-pH Mo ${ }^{\vee}$ EPR signals very similar to those observed for WT SO can be developed by lowering the $\mathrm{pH}^{48}$ Free tyrosine in aqueous solution has a side-chain $\mathrm{p} K_{\mathrm{a}}$ of 10.1 , but this will be significantly shifted (to a lower value) by the presence of the highly basic residues in the active site of SO, so that one of the two observed $\mathrm{p} K_{\mathrm{a}}$ values of $\mathrm{R} 160 \mathrm{Q} \mathrm{SO}$ could be that of Tyr. ${ }^{343}$ The two low-pH species are quite similar EPR signals (different $g$-values, but similar $g$-anisotropies, a similar lack of resolved proton hyperfine splitting, and indistinguishable redox potentials), and it seems likely that the two low-pH species are structurally similar. Thus 
ionization of nearby $\mathrm{Tyr}^{343}$ might induce a subtle comformational change in the active site, which is reflected in the two different R160Q low-pH Mov EPR signals. A candidate for the second residue that influences the Mov EPR spectra might be the $\operatorname{Gln}^{160}$ residue, and we will return to considering this residue later.

The lack of resolved proton splitting in the two low-pH signals is important and has bearing on the structure of the signal giving species. The high-pH signal of wild-type SO has no resolved hyperfine splitting but nevertheless possesses a strongly coupled proton. This has been detected by the observation of formally forbidden $\Delta m_{I}= \pm 1$ transitions ${ }^{49}$ and by pulsed EPR spectroscopy. ${ }^{50}$ George postulated that the proton hyperfine tensor from the hydrogen in an $\mathrm{Mo}-\mathrm{OH}$ group is oriented close to the trimagic angle ${ }^{49}$ where the dipole coupling along each direction of $g_{x}, g_{y}$, and $g_{z}$ will be zero, while later work using pulsed EPR spectroscopy ${ }^{50}$ concluded that the proton splitting was hidden by rotation of the $\mathrm{Mo}-\mathrm{OH}$ group about the Mo-O bond to yield a static distribution of $\mathrm{Mo}-\mathrm{O}-\mathrm{H}$ orientations and a corresponding ensemble of hyperfine interactions. ${ }^{50,51}$ At present neither of these two alternatives has been definitively proven. Anion-bound species such as the phosphate, sulfite (or sulfate), and arsenite compexes also show no hyperfine splitting from an exchangeable proton $22,37,39-42$ because in these cases the Mo-OH group is lacking. No splitting from coupled exchangeable protons is detected in any R160Q EPR signal at X-band microwave frequencies. The lack of resolved proton hyperfine splittings in the R160Q low-pH signals suggests that either their protons are oriented in an unfavorable geometry (we will consider this further below) or alternatively the Mo-OH group has been displaced by coordinaton of sulfite which was used as a reductant to develop the MoV EPR signals or from sulfate (the product of the reduction). Although we cannot exclude it, ${ }^{52}$ we consider sulfur anion coordination the less likely of the two possibilities as identical Mov EPR signals were observed in redox titrations containing only traces of sulfite, and experiments using a large excess $(20 \mathrm{mM})$ of sulfite did not perturb the apparent $\mathrm{p} K_{\mathrm{a}}\left(\mathrm{p} K_{\mathrm{a} 2}\right)$ between R160Q high-pH and the R160Q low$\mathrm{pH}$ type 2 signals (not illustrated).

In marked contrast to wild-type SO, anions such as phosphate $22,39,53$ had no effect on the MoV EPR of R160Q sulfite 
oxidase. Figure 7 shows this for addition of $60 \mathrm{mM}$ phosphate to wildtype and R160Q SO. The characteristic MoV EPR signal of the phosphate complex ${ }^{22,53}$ is formed with the wild-type enzyme, whereas the effects of phosphate on R160Q are only very slight and not resolvable as any discrete $\mathrm{Mo}^{\vee}$ signal under the conditions of our experiments. This is consistent with the proposed role of $\operatorname{Arg}^{160}$ in stabilizing anion complexes.
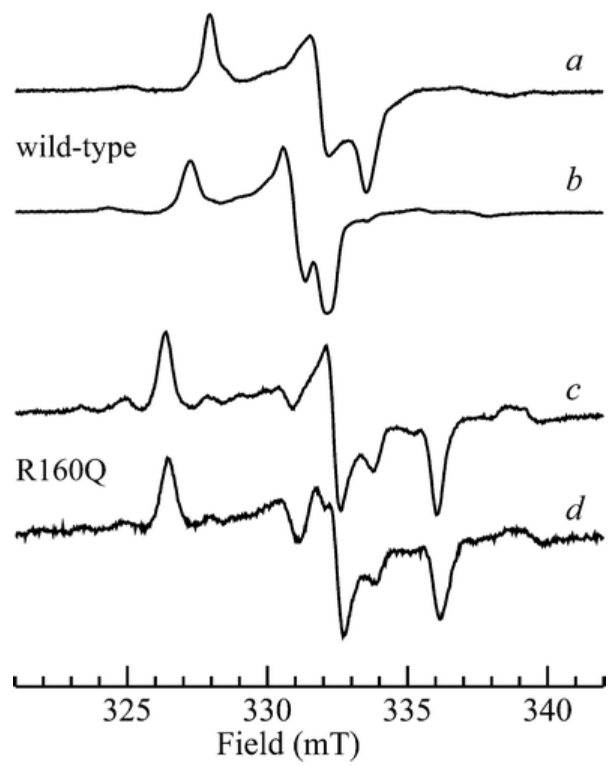

Figure 7 Effects of addition of phosphate on $\mathrm{Mo}^{\vee}$ EPR signals of wild-type and R160Q sulfite $(\mathrm{pH} 8)$, showing the wild-type enzyme in the absence $(a)$ and presence $(b)$ of $60 \mathrm{mM}$ sodium phosphate and R160Q enzyme in the absence $(c)$ and presence $(d)$ of $60 \mathrm{mM}$ sodium phosphate.

\section{Molecular Modeling and the Structure of the Mutant}

Molybdenum Site. The six-coordinate active site of the oxidized enzyme is of considerable interest. The obvious candidates for the additional ligand to molybdenum are $\mathrm{O}_{\varepsilon}$ and $\mathrm{N}_{\varepsilon}$ of Gln. ${ }^{160}$ Amides can potentially coordinate metal ions in three different ways: first through the $-\mathrm{NH}_{2}$ group of the amide, second via a coordinate bond through the carbonyl of the amide, and third via formation of the resonance form imidic acid $[-(\mathrm{HN}=) \mathrm{C}-\mathrm{OH}]$ and binding metal through the oxygen.

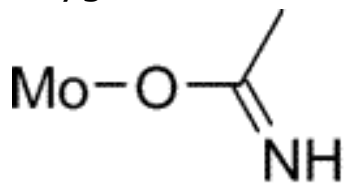

imidic

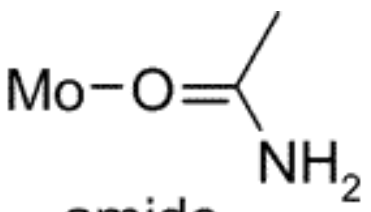

amide

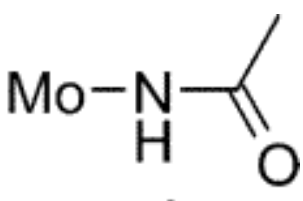

amino

Journal of the American Chemical Society, Vol 129, No. 30 (August 1, 2007): pg. 9421-9428. DOI. This article is (C) American Chemical Society and permission has been granted for this version to appear in e-Publications@Marquette. American Chemical Society does not grant permission for this article to be further copied/distributed or hosted elsewhere without the express permission from American Chemical Society. 
We note in passing that the first of these two forms is related by protonation of the amide group, which provides another possible candidate for the origin of the $\mathrm{pH}$ induced changes observed in the $\mathrm{Mo}^{\mathrm{V}}$ EPR (i.e., between low-pH types 1 and 2). A search of the Cambridge Structural Database ${ }^{33}$ reveals MoVI cis-dioxo examples of all three modes of coordination. For ligands coordinated approximately trans to one $\mathrm{Mo}=\mathrm{O}$ the Cambridge database gives average bond lengths of $2.21,2.22$, and $2.30 \AA$ for bonds formulated as imidic, amide, and amino coordinations, respectively. An alternative explanation of the distant oxygen might be an additional water or $-\mathrm{OH}$ ligand to Mo that is somehow stabilized by the presence of GIn. ${ }^{160}$ We tested the hypothesis of $\mathrm{Gln}^{160}$ coordination using constrained density functional theory (DFT) calculations of the active site structure. DFT calculations have to be limited to a small number of atoms because the processor time required scales approximately as the square of the number of electrons considered in the calculation. We truncated the active site structure at the furan ring of the molybopterin and at the alpha carbons of $\mathrm{Cys}^{207}$ and $\mathrm{Gln}^{160}$ (Figure 8), but we also constrained the four most distant atoms of the furan ring (i.e., not the ditholene carbons) and the amino acid alpha carbons to their crystallographically determined positions. ${ }^{13}$ Molybdenum coordination by a carbonyl was not supported by our calculations, as in all cases tested the carbonyl dissociated. Similarly $\mathrm{Mo}-\mathrm{OH}$ and $\mathrm{Mo}-\mathrm{OH}_{2}$ were found to be unstable in our calculations. On the other hand, both the nitrogen-coordinated amide and the oxygen-coordinated imide structures readily converged, with very close to the same minimum energy. EXAFS alone cannot distinguish between Mo- $\mathrm{O}$ and Mo $-\mathrm{N}$ coordination, and we are thus unable to discriminate between oxygen and nitrogen as the ligand. The energy of the nitrogen coordinated species was marginally lower $(0.3$ $\mathrm{eV}$ ) than that of the oxygen coordinated species, but the correspondence between the DFT of the oxygen coordinated species and the EXAFS-derived bond lengths is much better for the oxygenbound complex (although the trans-elongated $\mathrm{Mo}-\mathrm{S}_{2}$ ' bond length is slightly outside the usual $0.05 \AA$ error expected for unconstrained DFT). In either case, our calculations clearly demonstrate that GIn 160 can potentially coordinate Mo in an axial position to form a pseudooctahedral geometry. When the positional constraints described above were relaxed, the energy minimized structures were very similar (not illustrated), but the positions of the constrained carbons and their 
neighbors were significantly altered (especially the outer carbons of the amino acids). The DFT calculations also allow us to assign the elongated $\mathrm{Mo}-\mathrm{S}$ ligand to Mo-Si' (Figure 8, Table 1 ).

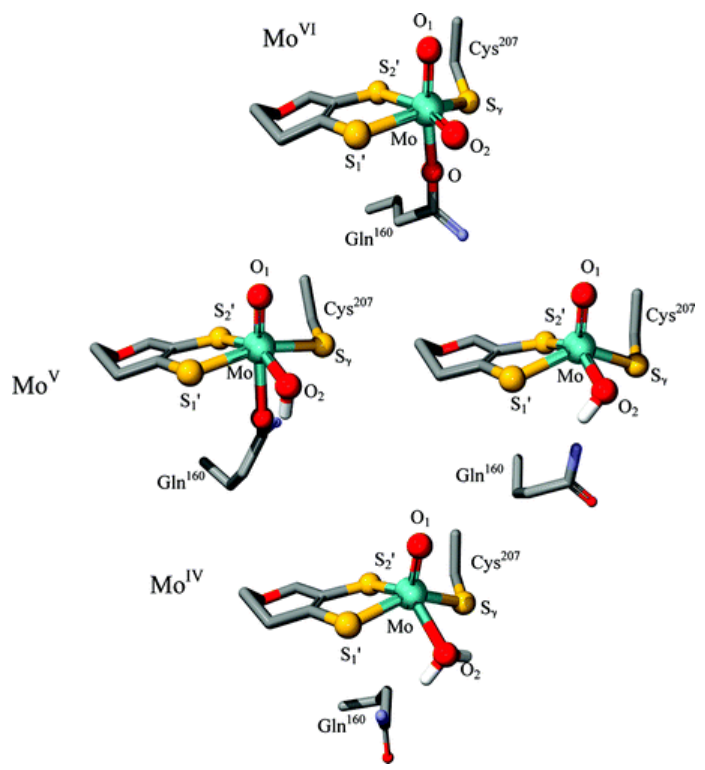

Figure 8 Density functional theory energy-minimized structure for the active site of $\mathrm{R} 160 \mathrm{Q} \mathrm{SO}$ in the three different oxidation states. All but the $\mathrm{Mo}-\mathrm{O}_{2}$ bound hydrogen atoms have been omitted for clarity.

Several different DFT optimized geometries for the reduced site were tested for both $\mathrm{Mo}^{\mathrm{V}}$ and $\mathrm{Mo}^{\mathrm{IV}}$ oxidation states. Selected interatomic distances obtained from DFT are compared with those from crystallography in Table 3 . For $\mathrm{Mo}^{\vee}$ species, the $\mathrm{O}_{2}$ atom was formulated as an $\mathrm{Mo}-\mathrm{OH}$ ligand, while, for $\mathrm{Mo}^{\mathrm{IV}}$ species, the $\mathrm{O}_{2}$ atom was formulated as $\mathrm{Mo}-\mathrm{OH}_{2}$. In both oxidation states, amine coordinated complexes were unstable and converged to a structure in which the amine had dissociated by abstracting a proton from the Mo - $\mathrm{OH}$ or $\mathrm{Mo}-\mathrm{OH}_{2}$. In the $\mathrm{Mo}^{\mathrm{IV}}$ oxidation state, $\mathrm{Gln}^{160}$ oxygencoordinated alternatives also dissociated from Mo, yielding a fivecoordinate active site with a very similar geometry to that determined by protein crystallography. An interesting difference is that the positions of the $\mathrm{O}_{\varepsilon}{ }^{1}$ and $\mathrm{N}_{\varepsilon}^{2}$ atoms of $\mathrm{Gln}^{160}$ are reversed from those shown in the crystal structure. As oxygen and nitrogen atoms will appear essentially identical to protein crystallography it seems possible that the position revealed by DFT is that found in the enzyme, although refinements with more amino acid residues in the active site would provide additional confidence. With the two $\operatorname{Gln}^{160}$ oxygen- 
coordinated $\mathrm{Mo}^{\vee}$ structures tested, amide-coordinated species converged to structures in which $\mathrm{Gln}^{160}$ did not coordinate the molybdenum, but the imidic-coordinated species converged to coordinated forms, and this suggests the possibility of a six-coordinate active site for this oxidation state. Our Mov EPR results suggest that the high-pH signal is quite similar to the analogous signal observed for wild-type enzyme, which is thought to be a five-coordinate species with an equatorial $\mathrm{Mo}-\mathrm{OH}$. In contrast, the two different low-pH signals, while somewhat similar to each other, are quite unlike any $\mathrm{Mo}^{\mathrm{V}}$ EPR signal obtained from the wild-type enzyme. Thus, we hypothesize that the signal-giving species for the $\mathrm{R} 160 \mathrm{Q}$ low-pH signals are sixcoordinate structures with $\mathrm{Gln}^{160}$ coordinated to Mo through $\mathrm{O}_{\varepsilon}$ of this residue. We further suggest that the signal-giving species for the R160Q high-pH signal corresponds to the five-coordinate structure in which $\mathrm{Gln}^{160}$ is dissociated from Mo. We now turn to the lack of observable hyperfine splitting from an exchangeable proton in the $\mathrm{R} 160 \mathrm{Q}$ low-pH signal. A Mov active site structure lacking an $\mathrm{Mo}-\mathrm{OH}$ ligand is very difficult to rationalize, and it seems likely that the absence of proton hyperfine splitting is the result of the proton being in an unfavorable geometry for a large hyperfine splitting in the signalgiving species. Our DFT energy-minimized structures show $\mathrm{Mo}-\mathrm{OH}$ proton orientations consistent with this hypothesis (Figure 8). For the six-coordinate species the proton of the $\mathrm{Mo}-\mathrm{OH}$ is oriented out of the plane of the paramagnetic ground-state molecular orbital (Figure 9), and this would give rise to much smaller hyperfine couplings than if it were oriented in the plane of this orbital. With the five-coordinate species, on the other hand, the proton is oriented close to the plane of the ground-state orbital (Figure 9), which would give rise to larger hyperfine couplings, and (at least in wild-type enzyme) the high-pH signal does possess a strongly coupled proton (although as we have discussed, it does not show a proton splitting at X-band microwave frequencies). Our DFT calculations thus provide a plausible explanation for the MoV EPR signals observed for R160Q SO. As we have discussed above, because sulfite was added to the samples to develop the Mov oxidation state, the further possibility of a sulfite-coordinated form must also be considered. As noted above, we consider this possibility unlikely but still a possibility. In this case the Mo-OH group would be replaced by coordinated sulfite $(\mathrm{Mo}-\mathrm{O}-\mathrm{S}(\mathrm{O}) \mathrm{OH})$, and proton hyperfine is not expected to be observed. DFT energy-minimized 
structures (not illustrated) converge to six-coordinate species that are similar to those containing $\mathrm{Mo}-\mathrm{OH}$ groups, showing hydrogen bonding between the $=\mathrm{S}-\mathrm{OH}$ proton and the $\mathrm{Mo}=\mathrm{O}$ group.
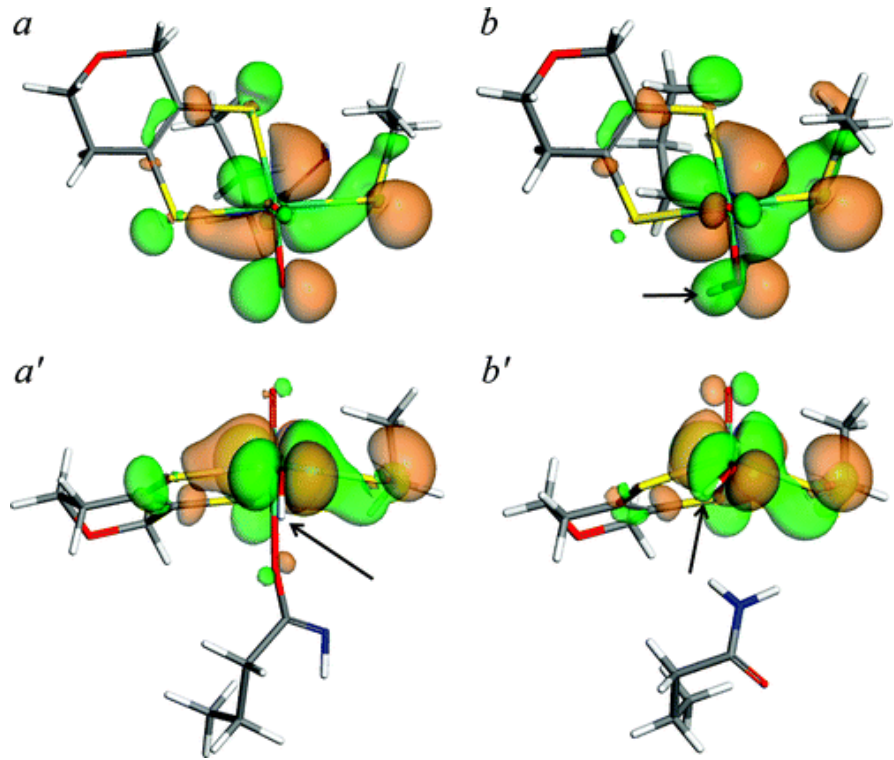

Figure 9 Highest occupied molecular orbitals for energy-minimized $\mathrm{Mo}^{\vee}$ structures with six-coordinate ( $a$ and $a^{\prime}$ ) and five-coordinate ( $b$ and $b^{\prime}$ ) molybdenum. Panels $a$ and $b$ show the view from above, looking approximately along the $M o=\mathrm{O}_{1}$ bond, while panels $a^{\prime}$ and $b^{\prime}$ show the view looking along the Mo $-\mathrm{O}_{2}$ bond. The orientation of the $\mathrm{Mo}-\mathrm{OH}$ proton is shown by the arrows and can be seen to be pointed away from the plane of the orbital in the six-coordinate case (in a the proton is hidden beneath the $\mathrm{Mo}-\mathrm{O}_{2}$ bond).

Table 3. Selected Interatomic Distances ${ }^{a}$ for DFT Computed Structures vs Crystallography

\begin{tabular}{|c|c|c|c|c|c|}
\hline bond & $\mathrm{Mo}^{\mathrm{VI}}$ & $\mathrm{Mov}^{\mathrm{V}}$ & $\mathrm{Mov}^{\mathrm{V}}$ & $\mathrm{Mo}^{\mathrm{IV}}$ & crystallography \\
\hline $\mathrm{Mo}-\mathrm{O}_{1}$ & 1.748 & 1.724 & 1.721 & 1.716 & 1.6 \\
\hline $\mathrm{Mo}-\mathrm{O}_{2}$ & 1.755 & 2.007 & 2.001 & 2.331 & 2.2 \\
\hline$M o-S_{1}{ }^{\prime}$ & 2.495 & 2.482 & 2.419 & 2.389 & 2.3 \\
\hline $\mathrm{Mo}-\mathrm{S}_{2}^{\prime}$ & 2.683 & 2.496 & 2.443 & 2.382 & 2.4 \\
\hline $\mathrm{Mo}-\mathrm{S}_{\mathrm{Y}}(\mathrm{C} 207)$ & 2.521 & 2.478 & 2.424 & 2.426 & 2.5 \\
\hline $\mathrm{Mo}-\mathrm{O}_{\varepsilon}(\mathrm{R} 160)$ & 2.256 & 2.375 & - & - & - \\
\hline
\end{tabular}

${ }^{a}$ Interatomic distances are given in $\AA{ }^{b}$ Values taken from the coordinates deposited in the protein structure database. ${ }^{13}$

Finally, the fundamental differences in coordination between oxidized wild-type SO and R160Q SO suggest a molybdenum-centered molecular basis for aspects of the kinetic incompetence of the mutant. Current postulated catalytic mechanisms for SO all involve coordination of substrate to molybdenum, and a variety of anion

Journal of the American Chemical Society, Vol 129, No. 30 (August 1, 2007): pg. 9421-9428. DOI. This article is @ American Chemical Society and permission has been granted for this version to appear in e-Publications@Marquette. American Chemical Society does not grant permission for this article to be further copied/distributed or hosted elsewhere without the express permission from American Chemical Society. 
complexes have been observed spectroscopically. ${ }^{22,40}$ In these complexes oxy-anions coordinate the metal via oxygen to form a Mo-O-A arrangement (where $A$ is the central atom of the oxyanion). ${ }^{39,40,53}$ In R160Q SO such coordination of substrate to the mutant enzyme would require displacement of coordinated $\mathrm{Gln}^{160}$ in the oxidized enzyme. Furthermore, the anion-complex stabilizing effects expected from the proximity of a highly basic residue such as Arg ${ }^{160}$ will be missing from the mutant enzyme, and our observation of the lack of anion effects in the MoV EPR of the mutant enzyme supports the hypothesis that anions are reluctant to bind. These observations provide explanations for the observed nearly 2 orders of magnitude increase in $K_{\mathrm{m}}$ for $\mathrm{R} 160 \mathrm{Q}$ relative to wild-type enzyme. ${ }^{7,8}$

According to simple Marcus theory ${ }^{56}$ intramolecular electrontransfer rates depend on the reorganization energy, and changing this can slow electron transfer. Thus, for wild-type sulfite oxidase both reduced and oxidized enzymes are five-coordinate, and only bondlength changes upon electron transfer contribute to the reorganization energy. With R160Q SO, the fully reduced $\mathrm{Mo}^{\mathrm{IV}}$ site is observed crystallographically to be five-coordinate, ${ }^{13}$ and this is supported by our DFT calculations and consistent with our EXAFS measurements. Intramolecular electron-transfer rates have been measured using flash photoreduction of the cytochrome $b$ with subsequent electron transfer to the oxidized Mo site, which is the opposite of the physiological direction. If the five-coordinate crystallographically observed structure for the R160Q SO Mo site is the same in solution, then electron transfer would involve dissociation of R160 from Mo which would in turn impact the reorganization energy and electron transfer.

In summary, we have shown that R160Q SO is coordinated by six ligands in the oxidized $\mathrm{Mo}^{\mathrm{VI}}$ state and have used DFT calculations with constraints derived from the crystal structure to conclude that the molybdenum of the mutant enzyme is coordinated by GIn, ${ }^{160}$ providing a molecular foundation for the kinetic incompetence of this mutant enzyme.

\section{Acknowledgment}

Portions of this work were carried out at the Stanford Synchrotron Radiation Laboratory which is funded by the Department of Energy Offices of 
Basic Energy Sciences and Biological and Environmental Research, with additional support from the National Institutes of Health, National Center for Research Resources. Work at the University of Saskatchewan was supported by a Canada Research Chair award (G.N.G.), the University of Saskatchewan, the Province of Saskatchewan, the Natural Sciences and Engineering Research Council, the National Institutes of Health, the Canadian Institute for Health Research, and the Canada Foundation for Innovation. Work at Duke University was supported by the National Institutes of Health (GM44283 and GM00091). The National Biomedical EPR Center is supported by the National Institutes of Health NIBIB EB001980.

\section{Supporting Information Available}

Tables of energy minimized coordinates for R160Q sulfite oxidase active sites in oxidized $\mathrm{Mo}^{\mathrm{VI}}$ and reduced $\mathrm{Mo}^{\mathrm{IV}}$ forms. This material is available free of charge via the Internet at http://pubs.acs.org.

\section{References}

${ }^{1}$ McLeod, R. M.; Farkas, W.; Fridovitch, I.; Handler, P. J. Biol. Chem. 1961, 236, 1841-1852.

${ }^{2}$ Cohen, H. L.; Betcher-Lange, S.; Kessler, D. L.; Rajagopalan, K. V. J. Biol. Chem. 1972, 247, 7759-7766.

3Johnson, J. L.; Rajagopalan, K. V. J. Biol. Chem. 1977, 252, 2017-2025.

${ }^{4}$ Rees, D. C.; Tezcan, A.; Haynes, C. A.; Walton, M. Y.; Andrade, S.; Einsle, O.; Howard, J. B. Philos. Trans. R. Soc. London, Ser. A 2005, 363, 971-984.

${ }^{5}$ Elliot, S. J.; McElhaney, A. E.; Feng, C.; Enemark, J. H.; Armstrong, F. J. Am. Chem. Soc. 2002, 124, 11612-11613.

${ }^{6}$ (a) Rajagopalan, K. V. Adv. Enzymol. Relat. Areas Mol. Biol. 1991, 64, 215-290. (b) Rajagopalan, K. V.; Johnson, J. L. J. Biol. Chem. 1992, 267, 10199-10202.

${ }^{7}$ Kisker, C.; Schindelin, H.; Pacheco, A.; Wehbi, W. A.; Garrett, R. M.; Rajagopalan, K. V.; Enemark, J. E.; Rees, D. C. Cell 1997, 91, 973-983.

${ }^{8}$ Garrett, R. M.; Johnson, J. L.; Graf, T. N.; Feigenbaum, A.; Rajagopalan, K. V. Proc. Natl. Acad. Sci. U.S.A. 1998, 95, 6394-6398.

${ }^{9}$ (a) Johnson, J. L.; Coyne, K. E.; Garrett, R. M.; Zabot, M.-T.; Dorche, C.; Kisker, C.; Rajagopalan, K. V. Hum. Mutat. 2002, 20, 74. (b) Lam, C. W.; Li, C. K.; Lai, C. K.; Tong, S. F.; Chang, K. Y.; Ng, G. S. F.; Yuen, Y. P; Cheng, A. W. F.; Chan, Y. Mol. Genet. Metab. 2002, 75, 91-95. ${ }^{10}$ Hille, R. Chem. Rev. 1996, 96, 2757-2816. 
${ }^{11}$ Steinberg, K. K.; Relling, M. V.; Gallagher, M. L.; Greene, C. N.; Rubin, C. S.; French, D.; Holmes, A. K.; Carroll, W. L.; Koontz, D. A.; Sampson, E. J.; Satten, G. A. Environ. Health Perspect. 2007, 115, 158-164.

${ }^{12}$ This mutation is G628A which is in the untranslated 5 '-region of the sulfite oxidase gene, which may somehow lead to decreased expression of sulfite oxidase. The occurrence of leukemia is also linked to the environmental presence of tungsten, ${ }^{11}$ and we can conjecture that the mutation decreases gene expression, which combined with molybdenum antagonism by tungsten significantly lowers sulfite oxidase levels. Further work is clearly needed to establish the mechanism.

${ }^{13}$ Karakas, E.; Wilson, H. L.; Graf, T. N.; Xiang, S.; Jaramillo-Busquets, S.; Rajagopalan, K. V.; Kisker, C. J. Biol. Chem. 2005, 280, 33506-33515.

${ }^{14}$ Feng, C.; Wilson, H. J.; Hurley, J. K.; Hazzard, J. T.; Tollin, G.; Rajagopalan, K. V.; Enemark, J. H. Biochemistry 2003, 42, 12235-12242.

${ }^{15}$ George, G. N.; Pickering, I. J.; Kisker, C. Inorg. Chem. 1999, 38, 2539-2540.

${ }^{16}$ Cramer, S. P.; Tench, O.; Yocum, M.; George, G. N. Nucl. Instrum. Methods 1988, A266, 586-591.

${ }^{17}$ http://ssrl.slac.stanford.edu/exafspak.html.

${ }^{18}$ George, G. N.; Garrett, R. M.; Prince, R. C.; Rajagopalan, K. V. J. Am. Chem. Soc. 1996, 118, 8588-8592.

${ }^{19}$ Doonan, C. J.; Stockert, A.; Hille, R.; George, G. N. J. Am. Chem. Soc. 2005, 127, 4518-4522.

${ }^{20}$ Rehr, J. J.; Mustre de Leon, J.; Zabinsky, S. I.; Albers, R. C. J. Am. Chem. Soc. 1991, 113, 5135-5140.

${ }^{21}$ Mustre de Leon, J.; Rehr, J. J.; Zabinsky, S. I.; Albers, R. C. Phys. Rev. B 1991, 44, 4146-4156.

${ }^{22}$ George, G. N.; Prince, R. C.; Kipke, C. A.; Sunde., R. A.; Enemark, J. E. Biochem. J. 1988, 256, 307-309.

${ }^{23}$ Dutton, P. L. Methods Enzymol. 1978, 24, 431-446.

${ }^{24}$ Clark, W. M. Oxidation-Reduction Potentials of Organic Systems; Williams and Wilkins: Baltimore, MD, 1960.

${ }^{25}$ Delley, B. J. Chem. Phys. 1990, 92, 508-517.

${ }^{26}$ Delley, B. J. Chem. Phys. 2000, 113, 7756-7764.

${ }^{27}$ Becke, A. D. J. Chem. Phys. 1988, 88, 2547-2553.

${ }^{28}$ Perdew, J. P.; Wang, Y. Phys. Rev. B 1992, 45, 13244-13249.

${ }^{29}$ Kutzler, F. W.; Natoli, C. R.; Misemer, D. K.; Donaich, S.; Hodgson. K. O. J. Chem. Phys. 1980, 73, 3274-3288.

${ }^{30}$ Harris, H. H.; George, G. N.; Rajagopalan, K. V. Inorg. Chem. 2006, 45, 493-495. 
${ }^{31}$ Normally, distinguishing between five-coordinate (e.g., oxidized wild-type SO) and six-coordinate (e.g., oxidized R160Q SO) sites would be challenging for EXAFS. The resolution of four discrete interactions (Figure 4) means that in this case it is straightforward to determine that oxidized R160Q SO is six-coordinate.

${ }^{32}$ George, G. N.; Hilton, J.; Temple, C.; Prince, R. C.; Rajagopalan, K. V. J. Am. Chem. Soc. 1999, 121, 1256-1266.

${ }^{33}$ Allen, F. H.; Kennard, O.; Watson, D. G. Struct. Correl. 1994, 1, 71-110.

${ }^{34} \mathrm{An}$ approximately linear relationship between the MoS bond length and OMoS bond angle is observed (correlation coefficient 0.955 ).

${ }^{35}$ Features attributable to molybdenum cannot readily be observed in the UV-visible spectrum of intact sulfite oxidase because of the relatively very intense absorption of the cytochrome moiety.

${ }^{36}$ We note that previous high-resolution EXAFS spectroscopy ${ }^{30}$ means that there is substantially less ambiguity in the number of Mo-O ligands present in wild-type enzyme. In this work EXAFS which extended to $k$ $=25 \AA^{-1}$ was used to resolve the Mo-O interaction from the overlapping Mo-S interaction.

${ }^{37}$ Lamy, M. T.; Gutteridge, S.; Bray, R. C. Biochem. J. 1980, 185, 397-403.

${ }^{38}$ Bray, R. C.; Gutteridge, S.; Lamy, M. T.; Wilkinson, T. Biochem. J. 1983, $211,227-236$.

${ }^{39}$ Pacheco, A.; Basu, P.; Borbat, P.; Raitsimring, A. M.; Enemark, J. H. Inorg. Chem. 1996, 35, 7001-7008.

${ }^{40}$ George, G. N.; Garrett, R. M.; Graf, T.; Prince, R. C.; Rajagopalan, K. V. J. Am. Chem. Soc. 1998, 120, 4522-4523.

${ }^{41}$ Bray, R. C.; Lamy, M. T.; Gutteridge, S.; Wilkinson, T. Biochem. J. 1982, $201,241-243$.

${ }^{42}$ We note that the Mov EPR signal attributed to a coordination of sulfite by Bray et al. ${ }^{41}$ has alternatively been attributed to a sulfate coordinated species [Astashkin, A. V.; Hood, B. L.; Feng, C.; Hille, R.; Mendel, R. R.; Raitsimring, A. M.; Enemark, J. H. Biochemistry 2005, 44, 13274-13281].

${ }^{43}$ Wilson, H. L.; Rajagopalan, K. V. J. Biol. Chem. 2004, 279, 15105-15113.

${ }^{44}$ Feng, C.; Wilson, H. L.; Hurley, J. K.; Hazzard, J. T.; Tollin, G.; Rajagopalan, K. V.; Enemark, J. H. J. Biol. Chem. 2003, 278, 2913-2920.

${ }^{45}$ Kappler, U.; Bennett, B.; Rethmeier, J.; Schwarz, G.; Deutzmann, R.; McEwan, A. G.; Dahl, C. J. Biol. Chem. 2000, 275, 13202-13212.

${ }^{46}$ Kappler, U.; Bailey, S. J. Biol. Chem. 2005, 280, 24999-25007.

${ }^{47}$ Doonan, C. J.; Kappler, U.; George, G. N. Inorg. Chem. 2006, 45, 7488-7492. 
NOT THE PUBLISHED VERSION; this is the author's final, peer-reviewed manuscript. The published version may be accessed by following the link in the citation at the bottom of the page.

${ }^{48}$ Kappler, U.; Bailey, S.; Feng, C.; Honeychurch, M. J.; Hanson, G. R.; Bernhardt, P. V.; Tollin, G.; Enemark, J. H. Biochemistry 2006, 45, 9696-9705.

${ }^{49}$ George, G. N. J. Magn. Reson. 1985, 64, 384-394.

${ }^{50}$ Astashkin, A. V.; Mader, M. L.; Pacheco, A.; Enemark, J. H.; Raitsimring, A. M. J. Am. Chem. Soc. 2000, 122, 5294-5302.

${ }^{51}$ Enemark, J. H.; Astashkin, A. V.; Raitsimring A. M. J. Chem. Soc., Dalton Trans. 2006, 3501-3514.

${ }^{52}$ DFT calculations support the possibility of a six-coordinate Mo with coordinated sulfite or sulfate. The geometry is very similar to that discussed below for protonated species, except that the $\mathrm{SOH}$ is hydrogen bonded to the axial MoO group (not illustrated).

${ }^{53}$ Gutteridge, S.; Lamy, M. T.; Bray, R. C. Biochem. J. 1980, 191, 285-288.

${ }^{54}$ Garrett, R. M.; Johnson, J. L.; Graf, T. N.; Feigenbaum, A.; Rajagopalan, K. V. Proc. Natl. Acad. Sci. U.S.A. 1998, 95, 6394-6398.

${ }^{55}$ Bray, R. C.; Lamy, M. T.; Gutteridge, S.; Wilkinson, T. Biochem. J. 1982, $201,241-243$.

${ }^{56}$ Gray, H. B.; Ellis, W. R., Jr. In Bioinorganic Chemistry; Bertini, I., Gray, H. B., Lippard, S. J., Valentine, J. S., Eds.; University Science Books: Mill Valley, CA, 1994; pp 315-363. 